\title{
SOCIAL MEDIA USE AMONG THE YOUTH. Results of THE ESPAD STUdy IN POLAND WITH REFERENCE TO OTHER EUROPEAN COUNTRIES
}

\section{KORZYSTANIE Z MEDIÓW SPOŁECZNOŚCIOWYCH WŚRÓD MŁODZIEŻY. WYNIKI BADAŃ ESPAD W POLSCE NA TLE WYBRANYCH KRAJÓW EUROPEJSKICH}

Justyna Iwona Klingemann, Janusz Sierosławski

Institute of Psychiatry and Neurology, Department of Studies on Alcoholism and Drug Dependence, Warsaw, Poland Instytut Psychiatrii i Neurologii, Zakład Badań nad Alkoholizmem i Toksykomaniami, Warszawa, Polska

Alcohol Drug Addict 2018; 31 (2): 87-106 DOI: https://doi.org/10.5114/ain.2018.79942

\begin{abstract}
Introduction: Polish ESPAD (European School Survey Project on Alcohol and Other Drugs) 2015 data on social media use among the youth are presented with reference to four other European countries (Greece, the Netherlands, Romania, and Sweden).

Material and methods: Logistic regression was performed to explore the relation between intensity of social media use and active social life and satisfactory peer relationships. Multivariable analysis was performed to explore the prevalence of social media use by teenagers and perception of the risk regarding use of social media.
\end{abstract}

\section{Streszczenie}

Wprowadzenie: Wyniki badania ESPAD (Europejskiego Programu Badań Szkolnych nad Używaniem Alkoholu i Narkotyków) 2015 dotyczące korzystania z mediów społecznościowych wśród polskich szesnastolatków ukazano na tle czterech wybranych krajów europejskich (Grecji, Holandii, Rumunii i Szwecji).

Materiał i metody: Analizę zależności między nasileniem korzystania $\mathrm{z}$ mediów społecznościowych a podejmowaniem aktywnego życia towarzyskiego wśród nastolatków oraz satysfakcjonującymi relacjami z rówieśnikami przeprowadzono z wykorzystaniem regresji logistycznej. Testowano też zróżnicowania w zakresie częstotliwości korzy-

Correspondence to/Adres do korespondencji: Justyna Irena Klingemann, Instytut Psychiatrii i Neurologii, Zakład Badań nad Alkoholizmem i Toksykomaniami, ul. Sobieskiego 9, 02-957 Warszawa, phone: +48 22 4582, e-mail: zulewska@ipin.edu.pl

Authors' contribution/Wkład pracy autorów: Study design/Koncepcja badania: J.I. Klingemann, J. Sierosławski; Data collection/Zebranie danych: J.I. Klingemann, J. Sierosławski; Statistical analysis/Analiza statystyczna: J. Sierosławski; Data interpretation/Interpretacja danych: J.I. Klingemann, J. Sierosławski; Acceptance of final manuscript version/Akceptacja ostatecznej wersji pracy: J.I. Klingemann, J. Sierosławski; Literature search/Przygotowanie literatury: J.I. Klingemann; Funds collection/Pozyskanie środków (finansowania): J. Sierosławski

No ghostwriting and guest authorship declared./Nie występują zjawiska ghostwriting i guest authorship.

Submitted/Otrzymano: 04.04.2018 • Accepted/Przyjęto do druku: 29.08.2018 
Results: Every fourth Polish teenager spends more than three hours per day on social networking. Social networking is an activity chosen more often by girls than boys and this relation is clear in all studied countries, despite different prevalence rates. Analysis shows that social networking for an hour per day or more increases the probability of teenagers having an active social life. Online gaming is less popular and is mainly a male phenomenon. Moreover, online gaming for more than an hour per day decreases the probability of satisfactory social relationships with peers.

Discussion: Social networking is one of the contemporary means of being together and despite spending time online, teenagers maintain an active social life and satisfactory peer relationships. Excessive online gaming seems to be a more risky phenomenon than social networking. It may lead to limited social life and unsatisfactory peer relations.

Conclusions: Professionals involved in prevention and addition therapy should take into account different levels of risk related to different online activities and should not lose sight of the potential and possibilities that being online carries with it.

Keywords: Poland, Social networks, Online games stania z mediów społecznościowych oraz percepcji ryzyka z tym związanego.

Wyniki: Co czwarty polski nastolatek spędza ponad trzy godziny dziennie, korzystając z serwisów społecznościowych. Korzystanie $\mathrm{z}$ tych serwisów jest zjawiskiem bardziej popularnym wśród dziewczynek niż chłopców i zależność ta jest wyraźna we wszystkich badanych krajach, pomimo różnej skali nasilenia tego zjawiska. Analiza pokazała, że aktywne korzystanie z serwisów społecznościowych godzinę dziennie lub dłużej zwiększa prawdopodobieństwo uczestniczenia w spotkaniach towarzyskich. Granie w gry online jest mniej powszechne i dotyczy przede wszystkim chłopców. Ponadto granie w gry online ponad godzinę dziennie zmniejsza prawdopodobieństwo satysfakcjonujących relacji z rówieśnikami.

Omówienie: Korzystanie z serwisów społecznościowych jest jednym ze sposobów na bycie z innymi - nastolatki często jednocześnie prowadzą aktywne życie towarzyskie, co przekłada się na satysfakcjonujące relacje $\mathrm{z}$ rówieśnikami. Tymczasem nadmierne granie w gry online może prowadzić do ograniczonego życia towarzyskiego i mało satysfakcjonujących relacji z innymi.

Wnioski: Zarówno osoby zajmujące się profilaktyką, jak i terapeuci uzależnień powinni mieć na uwadze ogromne zróżnicowanie w odniesieniu do szkodliwości aktywności dostępnych $\mathrm{w}$ internecie i nie tracić $\mathrm{z}$ oczu potencjału i możliwości, jakie niesie ze sobą bycie online.

Słowa kluczowe: Polska, serwisy społecznościowe, gry online

\section{- INTRODUCTION}

In the contemporary world, we spend so much time online using internet fix-linked equipment that being online may be seen as a contemporary default [1-5]. The internet has opened up new possibilities related to the ease and speed of communication across social and geographical divides. Young people take advantage of these technological benefits to a much greater extent than older generations satisfying belongingness needs in this manner [2, 6-9]. It is also worth taking into consideration that young people spend ever more time in the vir-

\section{W WROWADZENIE}

Współcześnie spędzamy tak dużo czasu online, korzystając z urządzeń podłączonych do internetu na stałe, że zaczyna być to traktowane jako współczesne status quo [1-5]. Internet otworzył nowe możliwości związane z łatwością i szybkością komunikowania się oraz z przekraczaniem granic społecznych i geograficznych. Młodzi ludzie korzystają z tych dobrodziejstw technologicznych w znacznie większym zakresie niż starsze pokolenia, zaspokajając tym samym potrzebę przynależności [2, 6-9]. Warto jednak pamiętać, że młodzież spędza coraz więcej czasu w świecie wirtualnym również dlatego, że różne 
tual world also because of various parental concerns about the real and imagined risks that limit their possibilities of spending their time outside the home $[2,8]$.

The terms "social media" and "social networks" are often used interchangeably in the literature. Meanwhile, their cognitive range differs because social media are internet solutions based on web 2.0 technologies that allow the creation and exchange of user generated content. Social media supply a wide range of activities from the support of social contacts, through gaming to intimate relations and the multi aspect character further increases their presence users' daily lives. In 2015 , the average social media user was active 1.7 hours per day in the USA, 1.5 in the UK and 3.7 in the Philippines, which was the highest value [2]. Data indicates that for many people this is an important and popular way of spending their free time allowing contact with others without space or time limitations.

Social media are equally social networks, instant messengers, microblogs, online gaming and online dating.

Social networks are made up of internet portals serving to create and promote own profiles and build social networks based on similar interests and common private or professional life $[2,10-12]$. Social networks are treated as one of the forms of self-expression in the contemporary world. The younger generation of researchers, who have grown up in a world in which technology was an integral part of everyday experience, indicate that for their generation, being connected up with other people and sources of information, irrespective of place and time, is an existing and expected state, a contemporary status quo $[2,13]$.

The most popular and unusually active social network is Facebook, which was created in 2004 [2, 10, 12]. In 2016, Facebook was used by one in five of the world's inhabitants, with 510,000 comments and 136,000 photographs posted every minute [2]. This is not however the only social networking service. Instagram, allowing photo sharing was created in 2010, while in 2011 Snapchat was created to facilitate mobile phone communication of news, film and photo content that is removed automatically niepokoje rodzicielskie dotyczące rzeczywistych i wyobrażonych zagrożeń ograniczają im możliwość spędzania czasu poza domem $[2,8]$.

Pojęcia „mediów społecznościowych” (social media) oraz „serwisów społecznościowych” (social networks) są w literaturze często używane wymiennie. Tymczasem ich zakres pojęciowy jest różny. Media społecznościowe to internetowe rozwiązania opierające się na technologicznych podstawach web 2.0, umożliwiające tworzenie i wymianę treści wygenerowanych przez użytkowników. Media społecznościowe dostarczają szerokiego zakresu aktywności - od podtrzymywania kontaktów towarzyskich, poprzez wspólne granie, po próby nawiązania relacji intymnych - a wieloaspektowość zwiększa jeszcze ich zakorzenienie $\mathrm{w}$ życiu codziennym użytkowników. W 2015 r. przeciętny użytkownik mediów społecznościowych korzystał z nich 1,7 godziny dziennie w USA, 1,5 godziny w Wielkiej Brytanii i 3,7 godziny na Filipinach (najwyższa wartość) [2]. Dane te wskazują, że dla wielu osób jest to istotny i popularny sposób spędzania wolnego czasu, pozwalający na kontakt $\mathrm{z}$ innymi, bez względu na ograniczenia przestrzenne i czasowe.

Media społecznościowe to zarówno serwisy społecznościowe (social networks), komunikatory (instant messengers), mikroblogi (microblogs), gry społecznościowe (online gaming), jak i portale randkowe (online dating).

Serwisy społecznościowe to portale internetowe służące do tworzenia i podtrzymywania własnych profili oraz budowania sieci społecznych, które opierają się na podobnych zainteresowaniach, wspólnym życiu zawodowym lub prywatnym [2, 10-12]. Serwisy społecznościowe są traktowane jako jeden ze sposobów wyrażania siebie we współczesnym świecie. Młodsze pokolenia badaczy, dorastających $\mathrm{w}$ świecie, w którym technologia była integralną częścią codziennego doświadczenia, wskazują, że dla ich pokolenia bycie połączonym z innymi ludźmi oraz ze źródłami informacji, bez względu na miejsce i czas, jest stanem zastanym i oczekiwanym, współczesnym status quo $[2,13]$.

Najbardziej popularnym i niezwykle aktywnym serwisem społecznościowym jest Facebook, stworzony w 2004 r. [2, 10, 12]. W 2016 r. Facebook był używany przez co piątego mieszkańca Ziemi, co minutę umieszczano tam 510 tys. komentarzy i 136 tys. zdjęć [2]. Nie jest to jednak jedyny serwis społecznościowy. W 2010 r. stworzono Instagram, sieć umożliwiającą dzielenie się zdjęciami, w 2011 r. powstał Snapchat ułatwiający komunikację przy wykorzystaniu telefonów komórkowych poprzez wiadomości, filmy i zdjęcia, które są jednak usuwane 
soon after reading, which serves to increase online privacy and security [2]. In 2016, Snapchat was the most popular social networking service in the USA in the 13-24 year-old age group at $72 \%$ with Facebook at $68 \%$ and Instagram at $66 \%$ [2].

Instant messengers are applications allow the immediate transfer of news and information about the presence of users in the web, which greatly increases the opportunity to have direct conversation. The most popular are WhatsApp and Facebook Messenger, each with 1000 million active users [2].

Microblogs are a sort of internet diary made up of short notes no longer than one sentence and also photos and sound or film clips. They are either available to the public or to a group selected by the author of the entries. The most popular is Twitter with 313 million users, which allows for notes of 140 characters [2].

Online gaming is realised on an enormous scale e.g. MMORPGs (Massively Multiplayer Online Role-Playing Games) including the popular World of Warcraft. Thousands of players participate in these virtual world games communicating with each other and creating relations and interactions necessary to realise the game goals that may be taken further beyond the virtual world [14-16]. The popularisation of multi person online games has resulted in the socialisation of this entertainment as the player does not compete against computer-generated rivals but other human players connected via the internet. This is however a very specific form of online game and apart from it we can also identify internet strategic games that put a greater emphasis on tactical thinking, or FPS (First Person Shooter) type games in which the player sees the world through the eyes of a virtual warrior and has the task of fighting it out with other players with the aid of different kinds of weapons [16]. Yet another form of online gaming are sports games, simulators (flight or automobile) and online adaptations of traditional games like chess or gambling games (some with virtual money, others with the deposit of real funds) [16].

Online dating a form of social medium allowing for the formation of intimate relations and search for a partner, an example of which is automatycznie, krótko po ich odczytaniu - funkcja służąca wzmocnieniu prywatności i bezpieczeństwa online [2]. W 2016 r. Snapchat był najbardziej popularnym serwisem społecznościowym w USA (72\%) w grupie młodzieży w wieku 13-24, kolejnymi były Facebook (68\%) i Instagram (66\%) [2].

Komunikatory to aplikacje komputerowe pozwalające na natychmiastowe przesyłanie wiadomości i informujące o obecności użytkowników w sieci, co zwiększa szansę na prowadzenie bezpośredniej konwersacji. Najbardziej popularne komunikatory to WhatsApp oraz Facebook Messenger z 1000 milionów aktywnych użytkowników każdy [2].

Mikroblogi to rodzaj dzienników internetowych składających się z krótkich notek, zazwyczaj o długości jednego zdania, mogą to też być zdjęcia, klipy dźwiękowe czy filmowe. Są dostępne publicznie lub przeznaczone dla grupy wyselekcjonowanych przez autora czytelników. Najbardziej popularnym przykładem jest Twitter - 313 milionów użytkowników - który zezwala na notki o długości do 140 znaków [2].

Gry społecznościowe to gry online realizowane na ogromną skalę, np. MMORPGs (massively multiplayer online role-playing games), do których należy popularny World of Warcraft. W tych grach - prowadzonych w wirtualnych światach - uczestniczą tysiące graczy, którzy komunikują się ze sobą, tworzą relacje i interakcje konieczne do realizacji celów gry, ale też możliwe do przeniesienia poza świat wirtualny [14-16]. Upowszechnienie wieloosobowych gier online spowodowało uspołecznienie tej rozrywki, gdyż gracz nie rywalizuje $\mathrm{z}$ przeciwnikami wygenerowanymi przez komputer, lecz z innymi graczami połączonymi za pośrednictwem sieci. Jest to jednak bardzo specyficzny rodzaj gier online, poza nimi możemy wyróżnić też: sieciowe gry strategiczne, które kładą większy nacisk na myślenie taktyczne, czy też gry typu FPS (first person shooter), w których gracz widzi świat oczami wirtualnego bohatera, a jego zadaniem jest walka za pomocą broni z innymi graczami [16]. Jeszcze innym typem są gry sportowe, symulatory (lotnicze lub samochodowe) oraz adaptacje online gier tradycyjnych (np. szachy) lub gier hazardowych (w niektórych gra się wirtualnymi pieniędzmi, inne wymagają obstawienia realnych kwot) [16].

Portale randkowe to medium społecznościowe umożliwiające nawiązanie relacji intymnych i służące do poszukiwania partnera; przykładem 
the popular Tinder. Studies show that their popularity is increasing all the time and $60 \%$ of internet users are of the opinion that dating sites are a good way of getting to know people [2].

Some authors suggest that social media respond to basic human needs like safety, belongingness, esteem, self-fulfilment needs, which explains their popularity and wide presence $[5,17,18]$. At the same time there are many authors who indicate the risks both of being online and too deep engagement in social media [12]. This excessive involvement in the internet has been called internet addiction in the past and there were even attempts to include this phenomenon into DSM-5 classification. Currently problematic internet use is what is being considered [1, 19-23]. Apart from the general criticism of this concept concerning excessive pathologisation of everyday life [1, 21, $24,25]$, the fact was indicated that the internet is a medium allowing a range of different activities of a highly varied potential level of harm like for example online gambling, pornography or social networks $[1,9,26,27]$. This at the same time raises the question of what in fact causes the harm; the internet as a medium that is in itself problematic or dependency creating, or what is facilitated thanks to the internet. Like in the case of alcohol dependence, it is not the bottle that is the problem, but its contents. So the internet as a medium does not have a problem character and if we talk about problem internet use, then we are thinking of concrete activities like online gaming or pornography $[2,10,26]$.

Researchers indicate that teenagers have a higher risk of problem social media use mainly because they are its most frequent users [28]. As studies show, nearly $90 \%$ of Polish adolescents between 14 and 17 years of age own at least one social media profile $[11,12]$. Furthermore, one of the causes of excessive involvement in social network services is FOMO - the Fear of Missing Out, a sense that others gain important and interesting experiences without our participation [29-31]. Another phenomenon similar to FOMO is Nomophobia, that means no mobile phone phobia, the anxiety associated with not having our mobile phone with us [32].

Kuss \& Griffiths [2] suggest that if dependency on the internet is not a matter of technology dependency but being in contact with others and enjoyment resulting from their positive comments jest popularny Tinder. Badania wskazują, że ich popularność stale rośnie, a $60 \%$ użytkowników internetu jest zdania, że portale randkowe to dobry sposób na poznanie innych [2].

Niektórzy autorzy sugerują, że media społecznościowe odpowiadają na podstawowe potrzeby ludzkie - potrzebę bezpieczeństwa, przynależności, uznania i samorealizacji, co tłumaczy ich popularność oraz powszechność $[5,17,18]$. Jednocześnie jest wielu autorów, którzy wskazują na ryzyko związane zarówno $\mathrm{z}$ przebywaniem online, jak i ze zbyt głębokim zaangażowaniem w media społecznościowe [12]. W przeszłości takie nadmierne zaangażowanie nazywano uzależnieniem od internetu (internet addiction), były nawet próby włączenia tego zjawiska do klasyfikacji DSM-5. Obecnie wskazuje się raczej na problemowe używanie internetu (problematic internet use) [1, 19-23]. Poza ogólną krytyką tej koncepcji dotyczącą nadmiernej patologizacji życia codziennego $[1,21$, $24,25]$ wskazywano też na fakt, że internet jest medium umożliwiającym szereg różnych aktywności o bardzo zróżnicowanym, potencjalnym poziomie szkodliwości, np. hazard online, pornografia, serwisy społecznościowe [1, 9, 26, 27]. Tym samym powstaje pytanie, co tak naprawdę szkodzi - internet jako medium samo $\mathrm{w}$ sobie problemowe czy uzależniające, czy też to, co dzięki internetowi zostaje ułatwione. Tak jak w przypadku uzależnienia od alkoholu, to nie butelka jest problemem, lecz jej zawartość, tak internet jako medium nie ma problemowego charakteru, a jeśli mówimy o problemowym używaniu internetu, to mamy na myśli konkretne aktywności, takie jak gry online czy pornografię $[2,10,26]$.

Badacze wskazują, że nastolatki są narażone na podwyższone ryzyko problemowego korzystania z mediów społecznościowych, głównie dlatego, że są ich najczęstszymi użytkownikami [28]. Jak pokazują badania niemal $90 \%$ polskich nastolatków w wieku 14-17 lat ma przynajmniej jeden profil $\mathrm{w}$ mediach społecznościowych $[11,12]$. Ponadto jedną z przyczyn nadmiernego zaangażowania w serwisy społecznościowe jest zjawisko FOMO (fear of missing out - lęk przed byciem pominiętym) - poczucie, że inni zdobywają ważne i ciekawe doświadczenia bez nas [29-31]. Innym zjawiskiem, zbliżonym do FOMO, jest nomofobia (nomophobia - no mobile phone phobia) - niepokój związany z tym, że nie mamy przy sobie telefonu komórkowego [32].

Kuss and Griffiths [2] sugerują, że jeśli uzależnienie od internetu nie jest kwestią uzależnienia od technologii, ale od bycia $\mathrm{w}$ kontakcie $\mathrm{z}$ innymi i za- 
and "likes", then perhaps we ought to be talking about a dependency on social media. Researchers conclude that a consequence of excessive internet use may be the impoverishment of social skills, preference of constant contact over understanding and commitment so in effect "being together but alone" $[2,33,34]$.

Other studies indicate that individuals neglect rest, sleep, work, school, personal hygiene and social relations in favour of spending time online, which may lead to health problems, social isolation, low quality of life, conflicts with close ones and even suicidal thoughts $[1,7,26$, $35,36]$.

Subrahmanyam et al. [37] conducted a review of literature on the influence of home computer use on the development of children. Frequent computer use was linked to the raised risk of obesity, hand injury, epileptic seizures, changes in heart rhythm, a sense of loneliness and symptoms of depression. Computer games containing elements of violence influenced the occurrence of aggressive thoughts, an increased sense of hostility and a lower frequency of pro-social behaviour.

Many previous studies on problem use of social media were realised on small, unrepresentative samples using various tools and different diagnostic criteria, which hampered comparison across countries and often leads to exaggerated prevalence indicators $[2,10,28,38]$, though exceptions have occurred [39, 40]. For example, Bányai et al. [39] report that $4.5 \%$ of 5961 studied adolescents may be counted as part of the social media risk user group. An international study on almost 11,000 teenagers realised in six European countries indicated that social media use of more than 2 hours per day was linked to problems, limitation of other activities and worse results at school. Forty per cent of study participants were found to be in the risk group [40].

This article presents the results of the ESPAD study (European School Survey Project on Alcohol and Other Drugs) [41] showing the scale of social media use (social networking and online gaming) among Polish teenagers compared to their counterparts in four selected European countries (Greece, the Netherlands, Romania and Sweden). This subject was introduced to the ESPAD study in 2015. In this article, we shall try to dowolenia wynikającego $\mathrm{z}$ ich pozytywnych komentarzy i polubień, to może powinniśmy mówić o uzależnieniu od mediów społecznościowych. Badacze twierdzą, że konsekwencją nadmiernego używania internetu może być ubożenie umiejętności społecznych, przedkładanie wagi ciągłego bycia w kontakcie nad wagę porozumienia i zaangażowania, i w efekcie - bycie razem, ale samotnie [2, 33, 34].

Inne badania wskazują, że jednostki zaniedbują odpoczynek i sen, pracę, szkołę, higienę osobistą i relacje społeczne na rzecz spędzania czasu online, co może prowadzić do problemów zdrowotnych, izolacji społecznej, niższej jakości życia, konfliktów z bliskimi, a nawet myśli samobójczych $[1,7,26,35,36]$.

Subrahmanyam i wsp. [37] dokonali przeglądu literatury na temat wpływu używania komputerów domowych na rozwój dzieci. Częste używanie komputera wiązało się z podwyższonym ryzykiem otyłości, urazów dłoni, ataków epilepsji, zmian w rytmie serca, poczucia samotności i objawów depresyjnych. Gry komputerowe zawierające elementy przemocy wpływały na pojawianie się agresywnych myśli, wzmocnienie uczucia wrogości i obniżenie częstości zachowań prospołecznych.

Wiele wczesnych badań dotyczących problemowego korzystania z mediów społecznościowych było realizowanych na małych niereprezentatywnych próbach, przy użyciu różnych narzędzi, różnych kryteriów diagnostycznych, co utrudnia porównania między krajami i prowadzi też często do zawyżania wskaźników rozpowszechnienia $[2,10$, $28,38]$, choć zdarzają się wyjątki $[39,40]$. Przykładowo Bányai i wsp. [39] donoszą, że 4,5\% z 5961 badanych nastolatków można zaliczyć do grupy ryzykownych użytkowników mediów społecznościowych. Międzynarodowe badanie z udziałem blisko 11 tys. nastolatków zrealizowane w 6 krajach europejskich wykazało, że korzystanie z mediów społecznościowych dłużej niż 2 godziny dziennie było związane z ograniczeniami innej aktywności i gorszymi wynikami w szkole. W grupie ryzyka znalazło się 40\% uczestników badania [40].

$\mathrm{W}$ artykule zaprezentowane zostaną wyniki badania ESPAD (Europejskiego Programu Badań Szkolnych nad Używaniem Alkoholu i Narkotyków) [41] obrazujące skalę korzystania z mediów społecznościowych (serwisów społecznościowych oraz gier online) przez polskich nastolatków na tle czterech wybranych krajów europejskich (Grecji, Holandii, Rumunii i Szwecji). Tę tematykę wprowadzono do badań ESPAD w 2015 r. W artykule 
answer questions about differences in social media use with respect to gender, on the perception of said media use and the influence of being online on the quality of peer relations. Even though we will be concentrating on the results of Polish studies, data from other countries of differing geography and culture reveal Polish data in their context and answer questions whether the observed relations are phenomena characteristic for what may be broadly understood as the European collective of sixteen-year-olds.

\section{- Material And methods}

\section{Variables and indicators}

The ESPAD auditory survey method study was described in a separate article [41].

The basis of the analysis presented in this article is individual data from the ESPAD database edition realised in the spring of 2015. All the study participants $\left(N_{\text {general }}=14,226 ; N_{\text {Poland }}=3289\right)$ were born in 1999. The cohort approach, with the cohort defined by the year of birth, was dictated by concerns for international comparability. The distribution of genders and sample size in specific countries is presented in Table I.

Analysis included above all variables like amount of time devoted to communication with others using social media: Twitter, Facebook and Skype and the amount of time spent playing online games i.e. World of Warcraft, Call postaramy się odpowiedzieć na pytania o różnice ze względu na płeć w zakresie korzystania $\mathrm{z}$ mediów społecznościowych, o percepcję korzystania z tych mediów oraz o wpływ bycia online na jakość relacji rówieśniczych. Pomimo że koncentrujemy uwagę na wynikach polskich, dane z innych krajów, zróżnicowanych geograficznie i kulturowo, ukazują polskie dane w ich kontekście i odpowiadają na pytanie, czy zaobserwowane relacje są zjawiskiem charakterystycznym dla szeroko rozumianej zbiorowości europejskich szesnastolatków.

\section{- Materiat I metody}

\section{Zmienne i wskaźniki}

Metodologia audytoryjnych badań ankietowych ESPAD została opisana w osobnym artykule [41].

Podstawą analiz prezentowanych w tym artykule są dane jednostkowe $\mathrm{z}$ bazy danych ESPAD edycji realizowanej wiosna $2015 \mathrm{r}$. Wszyscy uczestnicy badania $\left(N_{\text {ogótem }}=14226 ; N_{\text {Polska }}=3289\right)$ byli urodzeni w roku 1999. Podejście kohortowe, przy zdefiniowaniu kohorty przez rok urodzenia, podyktowane było względami międzynarodowej porównywalności. Rozkład płci oraz liczebności w poszczególnych krajach przedstawiono $\mathrm{w}$ tabeli I.

Do analizy włączono przede wszystkim takie zmienne, jak ilość czasu poświęcanego na komunikowanie się z innymi przy wykorzystaniu mediów społecznościowych, tj. Twittera, Facebooka, Skype’a, oraz ilość czasu poświęcanego na gry online:

Table I. Sample size by gender and country

Tabela I. Wielkość próby wg płci i kraju

\begin{tabular}{|c|c|c|c|c|}
\hline & \multicolumn{2}{|c|}{ Gender/Płeć } & \multirow{2}{*}{ Total/Ogółem } \\
\hline & & Boys/Chłopcy & Girls/Dziewczęta & \\
\hline \multirow{2}{*}{$\begin{array}{l}\text { Greece } \\
\text { Grecja }\end{array}$} & $N$ & 1583 & 1619 & 3202 \\
\hline & $\%$ & 49.40 & 50.60 & 100 \\
\hline \multirow{2}{*}{$\begin{array}{l}\text { Netherlands } \\
\text { Holandia }\end{array}$} & $N$ & 832 & 852 & 1684 \\
\hline & $\%$ & 49.40 & 50.60 & 100 \\
\hline \multirow{2}{*}{$\begin{array}{l}\text { Poland } \\
\text { Polska }\end{array}$} & $N$ & 1585 & 1704 & 3289 \\
\hline & $\%$ & 48.20 & 51.80 & 100 \\
\hline \multirow{2}{*}{$\begin{array}{l}\text { Romania } \\
\text { Rumunia }\end{array}$} & $N$ & 1711 & 1789 & 3500 \\
\hline & $\%$ & 48.90 & 51.10 & 100 \\
\hline \multirow{2}{*}{$\begin{array}{l}\text { Sweden } \\
\text { Szwecja }\end{array}$} & $N$ & 1263 & 1288 & 2551 \\
\hline & $\%$ & 49.50 & 50.50 & 100 \\
\hline \multirow{2}{*}{$\begin{array}{l}\text { Total } \\
\text { Ogółem }\end{array}$} & $N$ & 6974 & 7252 & 14,226 \\
\hline & $\%$ & 49.02 & 50.98 & 100 \\
\hline
\end{tabular}


of Duty and Grand. The social media perception was assessed with the use of variables describing the level of agreement with statements like "I believe I spend too much time participating in social media like Twitter, Facebook and Skype" and "My parents tell me that I spend too much time participating in social media like Twitter, Facebook and Skype". Indicators of peer relations were two variables: the level of satisfaction with relations with friends and frequency of going out with friends in the evening (to club, café or party). Furthermore, the analysis took into account socio-demographic variables (gender and country of study realisation).

\section{Statistical analysis}

The variation as regards the frequency of social media use and online gaming with respect to gender and country was tested with the $\chi^{2}$ test. In order to verify the agreement of self-assessed excessive social media use by students with that of their parents' perception we used Cohen kappa agreement coefficients $[42,43]$.

We conducted an analysis of the relationship between the intensity of social media use and online gaming and an active social life (going out in the evening socially at least 1-2 times per month) and peer relations assessed as at least satisfying using the logistic regression method. The models for logistic regression were devised for each country separately. Each model included two independent variables - social networking during a typical day within the last 30 days (not at all or less than half an hour, 1-3 hours and over 3 hours) and online gaming in a typical day in the last 30 days (range of questions as above).

\section{- Results}

The study results show that one in four Polish teenagers (26.6\%) spends over 3 hours a day using social networking sites (Table II). This is a result that is much lower than for the Netherlands (51.7\%), while similar to Sweden $(27.9 \%)$ and higher than Romania (19.7\%) and Greece (11.6\%).

The results are similar for Polish adolescents who do not use social networking services or do so only sporadically (18.4\%). In Greece and
World of Warcraft, Call of Duty, Grand. Percepcję mediów społecznościowych oceniano przy wykorzystaniu zmiennych określających poziom zgody ze stwierdzeniami: „Uważam, że spędzam za dużo czasu, uczestnicząc $\mathrm{w}$ mediach społecznościowych, takich jak Twitter, Facebook, Skype" oraz "Moi rodzice mówią, że spędzam za dużo czasu, uczestnicząc $w$ mediach społecznościowych, takich jak Twitter, Facebook, Skype”. Wskaźnikami relacji z rówieśnikami były zmienne: poziom satysfakcji w relacjach z przyjaciółmi oraz częstość wieczornych spotkań towarzyskich (dyskoteka, kawiarnia, prywatka). Ponadto $\mathrm{w}$ analizie brano pod uwagę zmienne społeczno-demograficzne (płeć oraz kraj realizacji badania).

\section{Analiza statystyczna}

Zróżnicowania w zakresie częstotliwości korzystania $\mathrm{z}$ mediów społecznościowych oraz grania online ze względu na płeć i kraj testowano przy użyciu testu $\chi^{2}$. Do oceny zgodności samooceny nadmiernego korzystania z mediów społecznościowych przez uczniów z postrzeganymi przez nich ocenami ich rodziców posłużono się współczynnikiem zgodności kappa Cohena [42, 43].

Metoda regresji logistycznej przeprowadzono analizę zależności między nasileniem korzystania z mediów społecznościowych oraz gier online a podejmowaniem aktywnego życia towarzyskiego (wychodzenie wieczorami na spotkania towarzyskie przynajmniej 1-2 razy w miesiącu) i relacjami z rówieśnikami ocenianymi jako przynajmniej satysfakcjonujące. Modele regresji logistycznej budowano dla poszczególnych krajów osobno. Do każdego modelu włączono dwie zmienne niezależne: korzystanie z serwisów społecznościowych typowego dnia w ciągu ostatnich 30 dni (wcale lub mniej niż pół godziny, 1-3 godziny, ponad 3 godziny) oraz granie w gry online typowego dnia w ciągu ostatnich 30 dni (kafeteria jak wyżej).

\section{- WYNIKI}

Wyniki badania wskazują, że co czwarty polski nastolatek (26,6\%) spędza ponad 3 godziny dziennie, korzystając z serwisów społecznościowych (tab. II). Jest to wynik znacznie niższy niż odsetek holenderskich nastolatków (51,7\%), zbliżony natomiast do odsetka w Szwecji (27,9\%), ale wyższy niż w Rumunii (19,7\%) i Grecji (11,6\%).

Podobnie plasują się wyniki dla polskich nastolatków, którzy nie korzystają serwisów społecznościowych lub korzystają z nich tylko sporadycznie 
Romania the percentage is higher at $23.2 \%$ and $20.3 \%$ respectively, similar in Sweden $(16.6 \%)$ and much lower in the Netherlands (8.2\%). The variation by country is statistically significant at 0.01 .

The use of social networking sites is more popular among girls than boys and this is the case both for Poland and other countries despite the differences in prevalence and intensity of this phenomenon. In Poland, like in Sweden, 30.3\% of girls and $22.6 \%$ of boys find themselves in the risk group as regards using social networking sites of which the proportion of girls is $30 \%$ higher than boys (Table II).

In the remaining countries the percentage of girls with risk use of social networking is around $60 \%$ higher than that of boys despite the differing prevalence, which is again the highest in the Netherlands (girls $63.3 \%$, boys $39.9 \%$ ) and lowest in Greece (girls $14.2 \%$ and boys $8.8 \%$ ) (Table II). Variations in terms of gender are statistically significant in each of the countries at 0.01 .

The results for the prevalence of social gaming among adolescents present a completely different picture. This is far less widespread than social networking as $71.6 \%$ of teenagers in Greece do not play at all or only sporadically, with the Polish results similar to that of Romania $(65.9 \%$ and $66.1 \%$ respectively) and in the Netherlands and Sweden slightly more than half of teenagers play rarely or do not at all (55.7\% and $54.7 \%$ respectively). On the other hand, $9.2 \%$ of Polish teenagers declared they play online games over 3 hours per day. This percentage is lower than that of the Netherlands (16.8\%) and Sweden (15.3\%), though higher than in Romania (6.7\%) and Greece (3.3\%). The variation in terms of country is significant at 0.01 .

Excessive social gaming is far more popular among boys. For example, $16.7 \%$ of Polish boys and only $2.3 \%$ of girls reported that on a typical day of play, they were online gaming for over 3 hours per day. In Poland, the percentage of playing over three hours per day in the case of boys is 7 times higher than girls and in the remaining countries these proportions are even higher (from 7 to even 16 times). The prevalence of gaming among boys is twice as high in Sweden and the Netherlands than in Poland (29\% and 30.4\% respectively). The lowest prevalence of excessive online gaming was not-
(18,4\%): w Grecji i Rumunii te odsetki sa wyższe (odpowiednio: 23,2\% i 20,3\%), zbliżone w Szwecji $(16,6 \%)$ i znacznie niższe w Holandii $(8,2 \%)$. Zróżnicowania ze względu na kraje są istotne statystycznie na poziomie istotności 0,01 .

Korzystanie z serwisów społecznościowych jest zjawiskiem bardziej popularnym wśród dziewcząt niż chłopców, i zależność ta wyraźnie zaznacza się zarówno w Polsce, jak i w pozostałych krajach, pomimo różnej skali rozpowszechnienia i nasilenia tego zjawiska. W Polsce, podobnie jak w Szwecji, $30,3 \%$ dziewcząt i 22,6\% chłopców znajduje się w grupie ryzyka pod względem korzystania $\mathrm{z}$ serwisów społecznościowych, tym samym odsetki dziewcząt są wyższe o ok. 30\% niż chłopców (tab. II).

W pozostałych krajach odsetki dziewcząt ryzykownie korzystających z serwisów społecznościowych są o ok. $60 \%$ wyższe niż odsetki chłopców, pomimo zróżnicowanego rozpowszechnienia, które znów jest najwyższe w Holandii (dziewczęta 63,3\%, chłopcy 39,9\%), a najniższe w Grecji (dziewczęta 14,2\%, chłopcy 8,8\%) (tab. II). Zróżnicowania ze względu na płeć są istotne statystycznie w każdym $\mathrm{z}$ krajów na poziomie istotności 0,01.

Zupełnie inny obraz pokazują wyniki rozpowszechnienia zjawiska grania $\mathrm{w}$ gry społecznościowe wśród nastolatków. Jest to zjawisko znacznie mniej powszechne od korzystania z serwisów społecznościowych. W Grecji 71,6\% nastolatków nie gra wcale lub gra sporadycznie, polskie odsetki zbliżone są do rumuńskich (odpowiednio: 65,9\% oraz $66,1 \%)$, w Holandii i Szwecji nieco ponad połowa nastolatków rzadko gra $\mathrm{w}$ gry online lub nie gra wcale (odpowiednio: $55,7 \%$ oraz $54,7 \%$ ). Z drugiej strony, 9,2\% polskich nastolatków zadeklarowało granie online ponad 3 godziny dziennie. Odsetek ten jest niższy od odsetka w Holandii $(16,8 \%)$ i Szwecji (15,3\%), ale wyższy niż w Rumunii $(6,7 \%)$ i Grecji (3,3\%). Zróżnicowania ze względu na kraje są istotne statystycznie na poziomie istotności 0,01 .

Nadmierne granie w gry społecznościowe jest zjawiskiem zdecydowanie bardziej popularnym wśród chłopców. Przykładowo, 16,7\% polskich chłopców i tylko 2,3\% dziewcząt wskazało, że w typowym dniu gra $\mathrm{w}$ gry społecznościowe ponad 3 godziny dziennie. W Polsce odsetki grania ponad 3 godziny dziennie w przypadku chłopców są 7 razy wyższe niż w przypadku dziewcząt, a w pozostałych krajach te proporcje są jeszcze wyższe - od 7 do nawet 16 razy. Rozpowszechnienie tego zjawiska wśród chłopców jest dwukrotnie wyższe w Szwecji i Holandii niż w Polsce (odpowiednio: $29 \%$ i $30,4 \%$ ). Najniższe rozpowszechnienie nad- 
Table II. Prevalence of social networks use and online gaming during last 30 days by gender and country (\%) Tabela II. Rozpowszechnienie korzystania z serwisów społecznościowych oraz gier online w ciągu ostatnich 30 dni wg płci i kraju (\%)

\begin{tabular}{|c|c|c|c|c|c|c|c|}
\hline & \multirow{2}{*}{ < 1 hour/godz. } & \multicolumn{3}{|c|}{$\begin{array}{c}\text { Social networks* } \\
\text { Serwisy społecznościowe* }\end{array}$} & \multicolumn{3}{|c|}{$\begin{array}{l}\text { Online gaming**} \\
\text { Gry online** }\end{array}$} \\
\hline & & $\begin{array}{l}<1 \text { hour } \\
\text { godz. }\end{array}$ & $\begin{array}{l}\text { 1-3 hours } \\
\text { godz. }\end{array}$ & $\begin{array}{l}>3 \text { hours } \\
\text { godz. }\end{array}$ & $\begin{array}{l}<1 \text { hour } \\
\text { godz. }\end{array}$ & $\begin{array}{l}\text { 1-3 hours } \\
\text { godz. }\end{array}$ & $\begin{array}{l}>3 \text { hours } \\
\text { godz. }\end{array}$ \\
\hline \multirow{3}{*}{$\begin{array}{l}\text { Poland } \\
\text { Polska }\end{array}$} & total/ogółem & 18.6 & 55.05 & 26.45 & 65.0 & 25.5 & 9.5 \\
\hline & boys/chłopcy $(n=1578)$ & 22.2 & 55.3 & 22.6 & 40.8 & 42.5 & 16.7 \\
\hline & girls/dziewczęta $(n=1698)$ & 14.9 & 54.8 & 30.3 & 89.2 & 8.5 & 2.3 \\
\hline \multirow{3}{*}{$\begin{array}{l}\text { Greece } \\
\text { Grecja }\end{array}$} & total/ogółem & 20.3 & 68.1 & 11.6 & 71.6 & 25.1 & 3.3 \\
\hline & boys/chłopcy $(n=1574)$ & 26.2 & 64.9 & 8.8 & 49.2 & 44.5 & 6.3 \\
\hline & girls/dziewczęta $(n=1617)$ & 14.6 & 71.2 & 14.2 & 93.5 & 6.1 & 0.4 \\
\hline \multirow{3}{*}{$\begin{array}{l}\text { Netherlands } \\
\text { Holandia }\end{array}$} & total/ogółem & 8.2 & 40.1 & 51.7 & 55.7 & 27.5 & 16.8 \\
\hline & boys/chłopcy $(n=829)$ & 12.5 & 47.5 & 39.9 & 28.2 & 41.4 & 30.4 \\
\hline & girls/dziewczęta $(n=847)$ & 3.9 & 32.8 & 63.3 & 82.4 & 14.0 & 3.5 \\
\hline \multirow{3}{*}{$\begin{array}{l}\text { Romania } \\
\text { Rumunia }\end{array}$} & total/ogółem & 23.2 & 57.0 & 19.7 & 66.1 & 27.2 & 6.7 \\
\hline & boys/chłopcy $(n=1691)$ & 29.1 & 54.9 & 16.0 & 46.0 & 41.6 & 12.4 \\
\hline & girls/dziewczęta $(n=1782)$ & 17.7 & 59.0 & 23.3 & 85.2 & 13.4 & 1.4 \\
\hline \multirow{3}{*}{$\begin{array}{l}\text { Sweden } \\
\text { Szwecja }\end{array}$} & total/ogółem & 16.6 & 55.6 & 27.9 & 54.7 & 30.0 & 15.3 \\
\hline & boys/chłopcy $(n=1232)$ & 20.7 & 55.1 & 24.2 & 22.8 & 48.3 & 29.0 \\
\hline & girls/dziewczęta $(n=1259)$ & 12.5 & 56.0 & 31.5 & 85.8 & 12.2 & 2.0 \\
\hline
\end{tabular}

${ }^{*}$ Time of social networking (hours) on a typical day during last 30 days./Liczba godzin w serwisach społecznościowych typowego dnia w ciagu ostatnich 30 dni.

**Time of online gaming (hours) on a typical day during last 30 days./Liczba godzin gry online typowego dnia w ciagu ostatnich 30 dni. Remarks/Uwagi: Statistical significance by country 0.01./Zróżnicowania ze względu na kraj są istotne statystycznie na poziomie istotności 0,01. < 1 Category includes 'none'/Kategoria < 1 obejmuje granie poniżej godziny, w tym wcale.

ed in Greece where it was $6.3 \%$ for boys and $0.4 \%$ for girls (Table II).

In contrast, girls, more than boys have the sense that they spend too much time on social networking sites. Up to $37.3 \%$ of Polish girls and $28.8 \%$ of boys believe they excessively use social networking sites. The percentage of girls in Poland is the lowest compared to the remaining studied countries. In Greece $54.7 \%$ of girls reported spending too much time on social networking sites, $58.3 \%$ in Sweden, $58.5 \%$ in Romania and $62.9 \%$ in the Netherlands (Table III). The discrepancies between girls and boys are the lowest in Romania, similar in Poland and Greece, while in the Netherlands and Sweden they are definitely the highest (Table II). Variation by gender is statistically significant in each of the countries at 0.01 .

Teenagers were asked not only if they felt that they spend too much time using social networking sites but also whether their parents tell them that they are spending too much time. It turns miernego grania online odnotowano $\mathrm{w}$ Grecji, gdzie odsetki wynosiły 6,3\% dla chłopców oraz $0,4 \%$ dla dziewcząt (tab. II).

Dla odmiany dziewczęta, bardziej niż chłopcy, mają poczucie spędzania nadmiernej ilości czasu w mediach społecznościowych. Aż 37,3\% polskich dziewcząt i $28,8 \%$ chłopców uważa, że nadmiernie korzysta $\mathrm{z}$ mediów społecznościowych. Odsetek dziewcząt $\mathrm{w}$ Polsce jest najniższy $\mathrm{w}$ porównaniu z pozostałymi badanymi krajami; w Grecji 54,7\% dziewcząt uznało, że spędza za dużo czasu, korzystając z mediów społecznościowych, w Szwecji - 58,3\%, w Rumunii - 58,5\%, w Holandii - 62,9\% (tab. III). Dysproporcje pomiędzy dziewczętami a chłopcami są najniższe w Rumunii, w Polsce i Grecji kształtują się na podobnym poziomie, natomiast $\mathrm{w}$ Holandii i Szwecji są zdecydowanie wyższe (tab. II). Zróżnicowania ze względu na płeć są istotne statystycznie w każdym z krajów na poziomie istotności 0,01.

Nastolatków zapytano nie tylko o to, czy mają poczucie, że spędzają zbyt dużo czasu, korzystając z mediów społecznościowych, ale również, czy ich rodzice 
Table III. Social media use perception by gender and country

Tabela III. Percepcja korzystania z mediów społecznościowych wg płci i kraju

\begin{tabular}{|c|c|c|c|c|c|}
\hline $\begin{array}{l}\text { Country } \\
\text { Kraj }\end{array}$ & $\begin{array}{l}\text { Poland } \\
\text { Polska }\end{array}$ & $\begin{array}{l}\text { Greece } \\
\text { Grecja }\end{array}$ & $\begin{array}{l}\text { Netherlands } \\
\text { Holandia }\end{array}$ & $\begin{array}{l}\text { Romania } \\
\text { Rumunia }\end{array}$ & $\begin{array}{l}\text { Sweden } \\
\text { Szwecja }\end{array}$ \\
\hline Boys/Chłopcy & $N=1563$ & $N=1568$ & $N=829$ & $N=1651$ & $N=1217$ \\
\hline $\begin{array}{l}\text { \% of boys who think they spend too } \\
\text { much time on social networking } \\
\% \text { chłopców, którzy uważają, że spędzają } \\
\text { za dużo czasu, korzystając z mediów } \\
\text { społecznościowych }\end{array}$ & 28.8 & 41.4 & 38.9 & 50.4 & 31.5 \\
\hline $\begin{array}{l}\text { \% of boys whose parents think } \\
\text { they spend too much time on social } \\
\text { networking } \\
\% \text { chłopców, których rodzice uważają, że } \\
\text { spędzają oni za dużo czasu, korzystając } \\
\text { z mediów społecznościowych }\end{array}$ & 33.4 & 35.4 & 31.5 & 40.1 & 29.8 \\
\hline $\begin{array}{l}\text { overlapping proportions A and B } \\
\text { \% chłopców, których rodzice uważają, że } \\
\text { spędzają oni za dużo czasu, korzystając } \\
\text { z mediów społecznościowych i którzy } \\
\text { zgadzają się z opinią rodziców }\end{array}$ & 18.3 & 24.6 & 21.6 & 30.1 & 18.8 \\
\hline Kappa & 0.404 & 0.422 & 0.408 & 0.397 & 0.443 \\
\hline Girls/Dziewczęta & $N=1693$ & $N=1616$ & $N=849$ & $N=1753$ & $N=1256$ \\
\hline $\begin{array}{l}\text { \% of girls who think they spend too much } \\
\text { time on social networking } \\
\% \text { dziewcząt, które uważają, że spędzają } \\
\text { za dużo czasu, korzystając z mediów } \\
\text { społecznościowych }\end{array}$ & 37.3 & 54.7 & 62.9 & 58.5 & 58.3 \\
\hline $\begin{array}{l}\text { \% of girls whose parents think they } \\
\text { spend too much time on social } \\
\text { networking } \\
\text { \% dziewcząt, których rodzice uważają, że } \\
\text { spędzają one za dużo czasu, korzystając } \\
\text { z mediów społecznościowych }\end{array}$ & 35.1 & 43.1 & 48.0 & 48.9 & 52.7 \\
\hline $\begin{array}{l}\text { overlapping proportions Aand B } \\
\text { \% dziewcząt, których rodzice uważają, że } \\
\text { spędzają one za dużo czasu, korzystając } \\
\text { z mediów społecznościowych i które } \\
\text { zgadzają się z opinią rodziców }\end{array}$ & 21.6 & 35.1 & 38.6 & 36.8 & 40.4 \\
\hline Kappa & 0.366 & 0.455 & 0.336 & 0.323 & 0.393 \\
\hline
\end{tabular}

AI think I spend too much time on social networking (strongly agree + partly agree)./Uważam, że spędzam za dużo czasu, uczestnicząc w serwisach społecznościowych - Twitter, Facebook, Skype (zdecydowanie tak + raczej tak).

${ }^{B}$ My parents say that I spend too much time on social networking (strongly agree + partly agree)./Moi rodzice mówią, że spędzam za dużo czasu, uczestnicząc w serwisach społecznościowych - Twitter, Facebook, Skype (zdecydowanie tak + raczej tak).

Remarks/Uwagi: Statistical significance by gender 0.01./Zróżnicowania ze względu na płeć są istotne statystycznie na poziomie istotności 0,01.

out that a higher percentage of teenagers express concern about their own behaviour online than they report parental concern in this respect. Only in Poland were these results similar with $33.2 \%$ of teenagers worrying that they spend too much time online and $34.3 \%$ indicating that their parents had expressed concern in this respect. These are not fully identical groups as the agreement of assessments by students about the belief that use of social media is too inten- zwracają im uwagę, że spędzają tam zbyt dużo czasu. Okazuje się, że wyższy odsetek nastolatków wyraża niepokój o własne zachowanie online niż raportuje niepokój rodziców w tym zakresie. Jedynie w Polsce wyniki te były zbliżone: $33,2 \%$ nastolatków niepokoi się o to, że spędza zbyt dużo czasu online oraz 34,3\% nastolatków wskazuje, że ich rodzice wyrażają niepokój z tym związany. Nie są to grupy w pełni tożsame - zgodność ocen uczniów co do przekonania, że zbyt intensywnie korzystają z mediów społeczno- 
Table IV. Social networks use and online gaming and going out regularly for social gatherings (logistic regression analysis)

Tabela IV. Korzystanie z serwisów społecznościowych oraz granie w gry online a regularne uczestniczenie w spotkaniach towarzyskich (analiza regresji logistycznej)

\begin{tabular}{|c|c|c|c|c|c|c|}
\hline & \multicolumn{5}{|c|}{$\begin{array}{c}\text { Going out regularly } \\
\text { Regularne uczestniczenie w spotkaniach towarzyskich }{ }^{\mathrm{A}} \\
\text { odds ratio }(\mathrm{Cl})\end{array}$} \\
\hline & & $\begin{array}{l}\text { Poland } \\
\text { Polska } \\
N=11,699\end{array}$ & $\begin{array}{l}\text { Greece } \\
\text { Grecja } \\
N=3166\end{array}$ & $\begin{array}{l}\text { Netherlands } \\
\text { Holandia } \\
N=1677\end{array}$ & $\begin{array}{l}\text { Romania } \\
\text { Rumunia } \\
N=3416\end{array}$ & $\begin{array}{c}\text { Sweden } \\
\text { Szwecja } \\
N=2449\end{array}$ \\
\hline \multirow{3}{*}{$\begin{array}{l}\text { Social networks } \\
\text { Serwisy } \\
\text { społecznościowe }^{\mathrm{B}}\end{array}$} & < 1 hour/godz. & 1.000 & 1.000 & 1.000 & 1.000 & 1.000 \\
\hline & 1-3 hours/godz. & $\begin{array}{c}2.574^{\star \star} \\
(2.121-3.123)\end{array}$ & $\begin{array}{c}3.177^{\star *} \\
(2.486-4.059)\end{array}$ & $\begin{array}{c}2.322^{\star *} \\
(1.584-3.404)\end{array}$ & $\begin{array}{c}1.718^{\star \star} \\
(1.450-2.037)\end{array}$ & $\begin{array}{c}1.973^{\star *} \\
(1.571-2.480)\end{array}$ \\
\hline & $>3$ hours/godz. & $\begin{array}{c}3.626^{\star \star} \\
(2.859-4.599)\end{array}$ & $\begin{array}{c}3.446^{\star *} \\
(2.228-5.331)\end{array}$ & $\begin{array}{c}3.015^{\star \star} \\
(2.066-4.401)\end{array}$ & $\begin{array}{c}2.730^{\star \star} \\
(2.169-3.434)\end{array}$ & $\begin{array}{c}2.686^{\star \star} \\
(2.055-3.512)\end{array}$ \\
\hline \multirow{3}{*}{$\begin{array}{l}\text { Online gaming } \\
\text { Gry online }\end{array}$} & < 1 hour/godz. & 1.000 & 1.000 & 1.000 & 1.000 & 1.000 \\
\hline & 1-3 hours/godz. & $\begin{array}{c}1.226^{\star} \\
(1.016-1.479)\end{array}$ & $\begin{array}{c}1.368^{\star} \\
(1.028-1.821)\end{array}$ & $\begin{array}{c}1.129 \\
(0.895-1.424)\end{array}$ & $\begin{array}{c}1.575^{\star \star} \\
(1.332-1.863)\end{array}$ & $\begin{array}{c}0.575^{\star *} \\
(0.474-0.698)\end{array}$ \\
\hline & $>3$ hours/godz. & $\begin{array}{c}0.818 \\
(0.617-1.084)\end{array}$ & $\begin{array}{c}0.656 \\
(0.365-1.179)\end{array}$ & $\begin{array}{c}0.721^{*} \\
(0.549-0.948)\end{array}$ & $\begin{array}{c}1.263 \\
(0.925-1.725)\end{array}$ & $\begin{array}{c}0.348^{\star \star} \\
(0.272-0.446)\end{array}$ \\
\hline
\end{tabular}

${ }^{*} p \leq 0.05 ;{ }^{* *} p \leq 0.01$

${ }^{\mathrm{A}}$ Going out in the evening (to a disco, cafe, party); 1 = at least once or twice a month; 0 = never or a few times per year./Wychodzenie wieczorami na spotkania towarzyskie (dyskoteka, kawiarnia, party); 1 = przynajmniej 1-2 razy w miesiącu; 0 = nigdy lub kilka razy do roku. ${ }^{\mathrm{B}}$ Time of social networking (hours) on a typical day during last 30 days./Liczba godzin w serwisach społecznościowych typowego dnia w ciagu ostatnich 30 dni.

'Time of online gaming (hours) on a typical day during last 30 days./Liczba godzin gry online typowego dnia w ciagu ostatnich 30 dni.

sive with their belief in their parents assessment varies from $18.3 \%$ in Poland to $30.1 \%$ in Romania. The kappa agreement coefficient varies from 0.443 in boys in Sweden to 0.397 in Romania and from 0.455 in girls in Greece to 0.323 in Romania. This coefficient takes into account not only agreement concerning confirmed over frequent social media use but also a lack of such a confirmation.

Regressive logistic analysis (Table IV) revealed that active use of social networking services for an hour or more per day increases the probability of taking part in social meetings, in relation to service use of less than one hour per day. These dependencies were visible in all studied countries though in Poland they were especially clear (2.6 times higher with 1-to-3 hours use per day and 3.6 times higher with over three hours of daily use).

Meanwhile, online gaming from 1 to 3 hours per day increases the probability of regular participation in social events, in relation to gaming of less than 1 hour per day, but only in Poland (1.2 times higher), Greece (1.4 times higher) and Romania (1.6 times higher). Furthermore, ściowych z ich przekonaniami co do ocen rodziców waha się od 18,3\% w Polsce do 30,1\% w Rumunii. Współczynnik kappa mierzący zgodność ocen waha się u chłopców od 0,443 w Szwecji do 0,397 w Rumunii oraz u dziewcząt od 0,455 w Grecji do 0,323 w Rumunii. Współczynnik ten uwzględnia nie tylko zgodność dotyczącą potwierdzeń zbyt częstego korzystanie z mediów społecznościowych, ale także braku takich potwierdzeń.

Analiza regresji logistycznej (tab. IV) pokazała, że aktywne korzystanie z serwisów społecznościowych godzinę dziennie lub dłużej zwiększa prawdopodobieństwo uczestniczenia $\mathrm{w}$ spotkaniach towarzyskich, w stosunku do korzystania z serwisów mniej niż godzinę dziennie. Zależności te były widoczne we wszystkich badanych krajach, choć w Polsce są szczególnie wyraźne (2,6 razy wyższe przy korzystaniu od 1 do 3 godzin dziennie i 3,6 razy wyższe przy korzystaniu ponad 3 godziny dziennie).

Tymczasem granie $\mathrm{w}$ gry online $1-3$ godziny dziennie zwiększa prawdopodobieństwo regularnego uczestniczenia w spotkaniach towarzyskich, w stosunku do grania mniej niż 1 godzinę dziennie, ale tylko w Polsce (1,2 raza), Grecji (1,4 raza) i Rumunii (1,6 raza). Ponadto zależność ta jest mniej wyraźna i znika w przypadku grania onli- 
Table V. Social networks use and online gaming and satisfactory peer relationships (logistic regression analysis) Tabela V. Korzystanie z serwisów społecznościowych oraz granie w gry online a satysfakcjonujące relacje z rówieśnikami (analiza regresji logistycznej)

\begin{tabular}{|c|c|c|c|c|}
\hline & & \multicolumn{3}{|c|}{$\begin{array}{c}\text { Satisfactory peer relationships }{ }^{\mathrm{A}} \\
\text { Satysfakcjonujące relacje } \mathrm{z} \text { rówieśnikami }{ }^{\mathrm{A}} \\
\text { odds ratio }(\mathrm{Cl})\end{array}$} \\
\hline & & $\begin{array}{c}\text { Poland } \\
\text { Polska } \\
N=11,252\end{array}$ & $\begin{array}{l}\text { Romania } \\
\text { Rumunia } \\
N=3368\end{array}$ & $\begin{array}{l}\text { Sweden } \\
\text { Szwecja } \\
N=2383\end{array}$ \\
\hline \multirow{3}{*}{$\begin{array}{l}\text { Social networks } \\
\text { Serwisy społecznościowe }{ }^{B}\end{array}$} & $<1$ hour/godz. & 1.000 & 1.000 & 1.000 \\
\hline & 1-3 hours/godz. & $\begin{array}{c}1.283^{\star} \\
(1.058-1.557) \\
\end{array}$ & $\begin{array}{c}0.806^{*} \\
(0.681-0.953) \\
\end{array}$ & $\begin{array}{c}1.276^{\star} \\
(1.018-1.600)\end{array}$ \\
\hline & > 3 hours/godz. & $\begin{array}{c}1.655^{\star \star} \\
(1.325-2.066)\end{array}$ & $\begin{array}{c}1.103 \\
(0.894-1.360)\end{array}$ & $\begin{array}{c}1.776^{\star *} \\
(1.378-2.289)\end{array}$ \\
\hline \multirow{3}{*}{$\begin{array}{l}\text { Online gaming } \\
\text { Gry online }^{c}\end{array}$} & $<1$ hour/godz. & 1.000 & - & - \\
\hline & 1-3 hours/godz. & $\begin{array}{c}0.752^{\star *} \\
(0.636-0.888) \\
\end{array}$ & - & - \\
\hline & > 3 hours/godz. & $\begin{array}{c}0.713^{*} \\
(0.552-0.921)\end{array}$ & - & - \\
\hline
\end{tabular}

${ }^{*} p \leq 0.05 ;{ }^{* *} p \leq 0.01$

A/ am usually satisfied with relationship with my friends; 1 = very satisfied or satisfied; $0=$ others./Moje relacje z przyjaciótmi sa satysfakcjonujące; 1 = bardzo satysfakcjonujące $i$ satysfakcjonujące; $0=$ pozostałe.

${ }^{\mathrm{B}}$ Time of social networking (hours) on a typical day during last 30 days./Liczba godzin w serwisach społecznościowych typowego dnia w ciagu ostatnich 30 dni.

'Time of online gaming (hours) on a typical day during last 30 days./Liczba godzin gry online typowego dnia w ciagu ostatnich 30 dni.

the relationship is less clear and disappears in the case of online gaming of over 3 hours per day. It is worth pointing out that in Sweden online gaming of over 1 hour per day reduces the probability of participation in social events, in relation to gaming of less than 1 hour per day, like in the Netherlands. Excessive gaming reduces the likelihood of having an active social life among teenagers.

Analysis of the influence of social media on satisfying peer relation (Table V) was possible only in Poland, Romania and Sweden. Regressive logistic analysis revealed that active use of social networking sites increases the likelihood of satisfying peer relations in Poland and Sweden. In Romania the dependency is reversed as using social networking sites from 1 to 3 hours per day reduces the likelihood of satisfying peer relations.

Analysis of the influence of online gaming on satisfying peer relations (Table V) was possible only in Poland. Over an hour of online gaming per day reduces the likelihood of satisfying peer relations, in relation to gaming of less than 1 hour per day. This suggests that active use of social networking sites and online gaming are two different ne ponad 3 godziny dziennie. Warto zaznaczyć, że w Szwecji granie w gry online ponad 1 godzinę dziennie zmniejsza prawdopodobieństwo regularnego uczestniczenia w spotkaniach towarzyskich, w stosunku do grania mniej niż 1 godzinę dziennie, podobnie w Holandii - nadmierne granie zmniejsza iloraz szans na aktywne życie towarzyskie wśród nastolatków.

Analiza wpływu korzystania $\mathrm{z}$ mediów społecznościowych na satysfakcjonujące relacje $\mathrm{z}$ rówieśnikami (tab. V) możliwa była tylko dla Polski, Rumunii i Szwecji. Analiza regresji logistycznej pokazała, że aktywne korzystanie $\mathrm{z}$ serwisów społecznościowych zwiększa iloraz szans na satysfakcjonujące relacje $\mathrm{z}$ rówieśnikami $\mathrm{w}$ Polsce i w Szwecji. W Rumunii zależność jest odwrotna - korzystanie z serwisów społecznościowych 1-3 godziny dziennie zmniejsza iloraz szans na satysfakcjonujące relacje z rówieśnikami.

Analiza wpływu grania w gry online na satysfakcjonujące relacje z rówieśnikami (tab. V) możliwa była tylko dla Polski. Granie w gry online ponad godzinę dziennie zmniejsza prawdopodobieństwo satysfakcjonujących relacji z rówieśnikami, w stosunku do grania mniej niż 1 godzinę dziennie. Sugeruje to, że aktywne korzystanie $\mathrm{z}$ serwisów społecznościowych i granie w gry online to dwa różne 
types of internet behaviour and excessive gaming may lead to limitation of social life in the "real world".

\section{- Discussion}

This article presents the results of ESPAD study 2015, illustrating the scale of social media use by Polish sixteen-year-olds compared to four selected European countries (Greece, the Netherlands, Romania and Sweden). We tried to answer the question to what extent being online is treated by teenagers as the contemporary status quo [1-5]. Study results show that four out of five Polish teenagers use social media at least one hour per day, like in Greece, Romania and Sweden, and only in the Netherlands was the phenomenon more widespread. Researchers indicate that one of the reasons for engaging in social networks is fear of being left out (FOMO), i.e. the sense that others are gaining interesting and important experiences without us [29-31].

The internet is a medium making possible a range of various activities of a potential level of harm [26, 27]. The study considered the use of social networking sites and online gaming. Many researchers indicate the risks related to being online and over engagement in social media $[7,26,35,36]$. The results of ESPAD indicate that one in four Polish teenagers spends more than 3 hours a day using social networking sites. This is a much lower result than for the Netherlands, close to that of Sweden and higher than for Romania and Greece. Differences between the countries with respect to the prevalence and intensity of social networking use suggests a need for seeking the socio-cultural factors affecting the scale of this phenomenon. From our study we can draw the conclusion that active social networking is one of the ways of being with others as using the services seems to at the same time lead to an active social life, which probably translates into satisfying peer relations. These dependencies, which are apparent in all the studied countries, are however contrary to scientific reports suggesting the opposite relationship [7].

It is not the case that the internet does not carry with it potential risks related to specific types of online activity. As the results of our research typy zachowań $\mathrm{w}$ internecie, a nadmierne granie może prowadzić do ograniczonego życia towarzyskiego w „świecie realnym”.

\section{- OMÓWIENIE}

W artykule zaprezentowano wyniki badania ESPAD 2015, obrazujące skalę korzystania z mediów społecznościowych przez polskich szesnastolatków na tle czterech wybranych krajów europejskich (Grecji, Holandii, Rumunii i Szwecji). Staraliśmy się odpowiedzieć na pytanie, w jakim stopniu bycie online jest traktowane przez nastolatki jako współczesne status quo [1-5]. Wyniki badania pokazują, że 4 z 5 polskich nastolatków korzysta $\mathrm{z}$ mediów społecznościowych przynajmniej godzinę dziennie, podobnie jak w Grecji, Rumunii i Szwecji, tylko w Holandii zjawisko to było bardziej powszechne. Badacze wskazują, że jedną $\mathrm{z}$ przyczyn angażowania się $\mathrm{w}$ serwisy społecznościowe jest lęk przed byciem pominiętym (FOMO) - poczucie, że inni zdobywają ważne i ciekawe doświadczenia bez nas [29-31].

Internet jest medium umożliwiającym szereg różnych aktywności o potencjalnym poziomie szkodliwości $[26,27]$ - w badaniu przyglądano się zjawisku korzystania z serwisów społecznościowych oraz gier online. Wielu badaczy wskazuje na ryzyko związane $\mathrm{z}$ przebywaniem online oraz ze zbyt głębokim zaangażowaniem $\mathrm{w}$ media społecznościowe $[7,26,35$, 36]. Wyniki badania ESPAD wskazują, że co czwarty polski nastolatek spędza ponad 3 godziny dziennie, korzystając z serwisów społecznościowych. Jest to wynik znacznie niższy niż w Holandii, bliski wynikom szwedzkim, ale wyższy niż w Rumunii i Grecji. Różnice pomiędzy krajami w zakresie rozpowszechnienia i nasilenia korzystania z serwisów społecznościowych sugerują potrzebę poszukiwania czynników społeczno-kulturowych wpływających na skalę tego zjawiska. $\mathrm{Z}$ naszego badania można wyciągnąć wniosek, że aktywne korzystanie z serwisów społecznościowych jest jednym ze sposobów na bycie z innymi - użytkownicy serwisów wydają się jednocześnie prowadzić aktywne życie towarzyskie, co prawdopodobnie przekłada się na satysfakcjonujące relacje $z$ rówieśnikami. Te zależności, widoczne we wszystkich badanych krajach, przeczą jednak doniesieniom naukowym sugerującym odwrotną zależność [7].

Nie jest tak, że internet nie niesie ze sobą potencjalnych zagrożeń związanych z konkretnymi typami aktywności online. Jak sugerują wyniki 
suggest, excessive online gaming may potentially increase the risk of less-than satisfactory peer relations and lead to social isolation. Research suggests that this is linked to the specifics of the gaming itself [16] as this form of entertainment involves the visual and auditory sense at the same time, demands concentration and focus and rapid decision-making. This may cause the ignoring of fatigue and hunger and may cause the player to lose the sense of time. Furthermore, many online games do not have a traditionally understood end. Often it is not possible to discover the whole game world as it is planned out to be enormous and is always being developed [16]. Of course, the most risky here are the games taking place non-stop in real time and if the player does not follow his character (be it country, institution or army) is left without care and may fall victim to another player [16]. Different types of online game differ in popularity. As far as nearly daily playing is concerned, multi person FPS type games are most popular account for $18.85 \%$ and MMORPG type $18.16 \%$, one-person games $9.28 \%$ and web strategic games $8.42 \%$ [16].

Social networking is more popular among girls than boys and this relationship is clear both in Poland and in the remaining countries despite the differences in the prevalence and intensity of this phenomenon. This is confirmed also by the results of other studies realised in Poland [11, 12]. However, online gaming is definitely more popular with boys. In Poland, the percentage of boys playing more than three hours per day is 7 times higher than that of girls and in the remaining countries these proportions are even greater. Kuss and Griffiths [27] suggest that involvement in different types of internet activity satisfies different needs. Girls do not do gaming online while they treat social networking as a means to satisfying their need to interact with other girls and the need to be understood, while boys satisfy the need for narcissistic gratification when they get involved in online gaming [27]. Wójcik [16] indicates that girls play not only more rarely but also less intensively than boys due to differing cultural patterns (rivalry and battle are traditionally masculine domains) and many of the most popular games are clearly profiled naszego badania, nadmierne granie online może potencjalnie zwiększać ryzyko mało satysfakcjonujących relacji z rówieśnikami oraz prowadzić do izolacji społecznej. Badacze wskazują, że wiąże się to ze specyfiką samego grania [16] - ta rozrywka angażuje jednocześnie zmysły wzroku i słuchu, wymaga koncentracji i skupienia oraz podejmowania szybkich decyzji. Może to powodować ignorowanie zmęczenia czy głodu oraz utratę poczucia upływu czasu. Ponadto wiele gier online nie ma tradycyjnie pojmowanego końca - często nie da się poznać świata gry, bo jest on zaplanowany z ogromnym rozmachem i stale rozbudowywany [16]. Oczywiście najbardziej ryzykowne są tu gry rozgrywające się non-stop w czasie rzeczywistym, jeśli gracz nie śledzi gry, jego postać (państwo, instytucja czy armia) pozostaje bez opieki i może paść ofiarą innego gracza [16]. Różne typy gier online różnią się popularnością: jeśli chodzi o granie prawie codziennie, najpopularniejsze okazują się wieloosobowe gry typu FPS (18,85\%) i typu MMORPG (18,16\%), gry dla jednego gracza $(9,28 \%)$ oraz sieciowe gry strategiczne $(8,42 \%)$ [16].

Korzystanie z serwisów społecznościowych jest bardziej popularne wśród dziewcząt niż chłopców i zależność ta rysuje się wyraźnie zarówno w Polsce, jak i w pozostałych krajach, pomimo różnej skali rozpowszechnienia i nasilenia tego zjawiska. Potwierdzają to również wyniki innych badań realizowanych $w$ Polsce $[11,12]$. Natomiast granie w gry społecznościowe jest zjawiskiem zdecydowanie bardziej popularnym wśród chłopców. Odsetki chłopców grających ponad 3 godziny dziennie są $\mathrm{w}$ Polsce 7 razy wyższe niż odsetki dziewcząt, a w pozostałych krajach te proporcje są jeszcze wyższe. Kuss i Griffiths [27] sugerują, że zaangażowanie się w różnego typu aktywności $\mathrm{w}$ internecie zaspokaja różnego rodzaju potrzeby. Dziewczęta nie grają w gry społecznościowe, za to używają serwisów społecznościowych w celu zaspokojenia potrzeby interakcji z innymi dziewczętami oraz potrzeby bycia zrozumianym, dla odmiany chłopcy zaspokajają potrzebę narcystycznej gratyfikacji, angażując się w gry online [27]. Wójcik [16] wskazuje, że dziewczęta grają nie tylko rzadziej, ale też mniej intensywnie niż chłopcy, ze względu na odmienne wzory kulturowe (rywalizacja i pojedynek to wartości tradycyjnie męskie), ponadto wiele najpopularniejszych gier jest wyraźnie sprofilowanych pod kątem odbiorców płci 
for the male consumer - the heroes are men and the themes concern wars, cars and football.

ESPAD study results do not confirm that of other studies suggesting a generational conflict and a greater concern linked to the use of social media expressed by parents than children [2]. In our study, it is the teenagers, especially the girls, who have a sense of spending excessive amounts of time on social media. Furthermore, a higher percentage of teenagers express concern about their own online behaviour than that reported by parents in this respect. It was only in Poland that these two results were similar.

\section{Study limitations}

One of the limitations of the ESPAD study is that it was not specially designed to research excessive social media use. On the contrary, the behaviour of teenagers online was its object only to a very limited extent and attention was directed mainly to the use of psychoactive substances. Social media researchers indicate the conceptual limitations of studies on the prevalence of excessive social media use linked to their a-theoretical character. The very phenomenon of risk social media use is not sufficiently conceptualised and the studies have still failed to answer the question why. Social media are also unusually dynamic and the progress of technology is extremely fast. Furthermore, there is an over emphasis on individual behaviour not taking into account the social context linked, for example, to socioeconomic conditions of the country that partially contribute to access to the internet, computers and smartphones. Apart from the monitoring of the spread of certain phenomena, it is worth conducting studies concentrated above all on the internet that are also of a qualitative character in order to deepen and explore the concerns expressed in this article.

\section{- Conclusions}

The internet opens up opportunities linked to the ease and speed of communication across social and geographic divides. For contemporary adolescents, the use of social media is one of the means of being with others as young people often have an active social life at the same męskiej - bohaterami są mężczyźni, a tematyka dotyczy wojen, samochodów i piłki nożnej.

Wyniki projektu ESPAD nie potwierdzają wyników badań sugerujących konflikt pokoleniowy oraz większy niepokój związany z korzystaniem z mediów społecznościowych wyrażany przez rodziców niż dzieci [2]. W naszym badaniu to nastolatki, a szczególnie dziewczęta, mają poczucie spędzania nadmiernej ilości czasu w mediach społecznościowych. Ponadto wyższy odsetek nastolatków wyraża niepokój o własne zachowanie online, niż raportuje niepokój rodziców w tym zakresie. Jedynie w Polsce wyniki te były zbliżone.

\section{Ograniczenia badania}

Jednym z ograniczeń prezentowanego tu projektu ESPAD jest fakt, że nie był on specyficznie zaprojektowany do badania nadmiernego korzystania $\mathrm{z}$ mediów społecznościowych, przeciwnie - zachowania nastolatków online stanowiły jego przedmiot w bardzo ograniczonym zakresie, a uwagę skierowano głównie na używanie substancji psychoaktywnych. Badacze mediów społecznościowych wskazują na konceptualne ograniczenia badań nad rozpowszechnieniem nadmiernego korzystania $\mathrm{z}$ mediów społecznościowych związane $\mathrm{z}$ ich ateoretycznym charakterem - samo zjawisko ryzykownego korzystania $\mathrm{z}$ mediów społecznościowych nie jest wystarczająco skonceptualizowane, a badania ciągle nie odpowiadają na pytanie dlaczego. Media społecznościowe to też zjawisko niezwykle dynamiczne - postęp technologiczny przebiega niezmiernie szybko. Ponadto zbyt duży nacisk kładzie się na indywidualne zachowania, $\mathrm{z}$ pominięciem kontekstu społecznego, związanego np. z warunkami socjoekonomicznymi danego kraju, które przekładają się częściowo na dostępność internetu, komputerów czy smartfonów. Poza monitorowaniem rozpowszechnienia pewnych zjawisk, warto realizować badania skoncentrowane przede wszystkim na internecie, również o jakościowym charakterze, w celu pogłębienia i wyjaśnienia zarysowanych $\mathrm{w}$ artykule kwestii.

\section{- WNIOSKI}

Internet otwiera nowe możliwości związane z łatwością i szybkością komunikowania się, przekraczając granice społeczne i geograficzne. Dla współczesnych nastolatków korzystanie z serwisów społecznościowych jest jednym ze sposobów na bycie $\mathrm{z}$ innymi - młodzi ludzie często jednocześnie prowadzą aktywne życie towarzyskie, co prze- 
time, which translates into satisfactory peer relations. Excessive online gaming seems to be a more worrying phenomenon than excessive social network use, and boys are especially exposed to the negative consequences linked to online gaming.

Polish qualitative studies on a group of young people indicating symptoms of internet excessive use showed high differentiation in terms of intensity of risk and harm in their patterns of internet use, in which only one of the studied categories could be considered to be overuse [5]. Similar ESPAD study results show that the internet is a medium that allows a range of activities of various risk levels. Both persons involved in prevention and addiction therapy ought to take note of the enormous variety related to the harm of activities available on the internet and should not lose sight of the potential and possibilities that being online carries with it. kłada się na satysfakcjonujące relacje $\mathrm{z}$ rówieśnikami. Nadmierne granie online wydaje się bardziej niepokojącym zjawiskiem niż nadmierne korzystanie z serwisów społecznościowych, a narażeni na negatywne konsekwencje związane $\mathrm{z}$ graniem online są szczególnie chłopcy.

W polskich badaniach jakościowych, obejmujących grupę młodzieży wykazującą symptomy nadużywania internetu, zaobserwowano duże zróżnicowanie nasilenia ryzyka i szkodliwości we wzorach korzystania $\mathrm{z}$ internetu, w tym tylko jedna z wyłonionych kategorii nosiła znamiona nadużywania [5]. Podobnie wyniki badań ESPAD pokazują, że internet jest medium umożliwiającym szereg aktywności o zróżnicowanym poziomie ryzyka. Zarówno osoby zajmujące się profilaktyką, jak i terapeuci uzależnień powinni mieć na uwadze ogromne zróżnicowanie dotyczące szkodliwości działań dostępnych $\mathrm{w}$ internecie i nie tracić $\mathrm{z}$ oczu potencjału i możliwości, jakie niesie ze sobą bycie online.

\section{Conflict of interest/Konflikt interesów}

None declared./Nie występuje.

\section{Financial support/Finansowanie}

Ministry of Science and Higher Education, Core funding for statutory R \& D activities, no 501-002-15008/ 501-002-16008/ 501-002-117008 / Ministerstwo Nauki i Szkolnictwa Wyższego, Temat statutowy, nr 501-002-15008./501-002-16008/ 501-002-117008.

\section{Ethics/Etyka}

The work described in this article has been carried out in accordance with the Code of Ethics of the World Medical Association (Declaration of Helsinki) on medical research involving human subjects, EU Directive (210/63/EU) on protection of animals used for scientific purposes, Uniform Requirements for manuscripts submitted to biomedical journals and the ethical principles defined in the Farmington Consensus of 1997.

Treści przedstawione w pracy są zgodne z zasadami Deklaracji helsińskiej odnoszącymi się do badań z udziałem ludzi, dyrektywami UE dotyczącymi ochrony zwierząt używanych do celów naukowych, ujednoliconymi wymaganiami dla czasopism biomedycznych oraz z zasadami etycznymi określonymi w Porozumieniu z Farmington w 1997 r.

\section{References/Piśmiennictwo}

1. Bergmark K, Stensson E, Bergmark A. Internet Addiction: The Making of a New Addiction. $J$ J Addic Ther 2016; 3(1): 022.

2. Kuss DJ, Griffiths MD. Social Networking Sites and Addiction: Ten Lessons Learned. Int J Environ Res Public Health 2017; 14: 1-17. DOI:10.3390/ijerph14030311.

3. Snickars P, Strömbäck P. Myten om Internet (the Myth of the Internet). Halmstad: Volante förlag; 2012.

4. Różański A. Media społecznościowe: współczesne środowisko edukacyjne czy „,yfrowe tsunami”? Annales Universitatis Mariae Curie-Skłodowska 2017; XXX(2), Sectio J: 205-16. 
5. Wójcik S. Korzystanie z internetu przez polską młodzież - studium metodą teorii ugruntowanej. Wyniki projektu EU NET ADB. Dziecko krzywdzone. Teoria, badania, praktyka 2013; 12(1): 13-33.

6. Kuntsche E, Simons-Morton B, Bogt T, Queija IS, Tinoco VM, Gaspar de Matos M, et al. Electronic media communication with friends from 2002 to 2006 and links to face-toface contacts in adolescence: an HBSC study in 31 European and North American countries and regions. Int J Public Health 2009; 54(S2): 243-50.

7. Trnka R, Martınkova Z, Tavel P. An integrative review of coping related to problematic computer use in adolescence. Int J Public Health 2016; 61: 317-327. DOI: 10.1007/ s00038-015-0693-8

8. Boyd D. It's Complicated: The Social Lives of Networked Teens. Yale, CT, USA: Yale University Press; 2014.

9. Kotyśko M, Izdebski P, Michalak M, Andryszak P, Pluto-Prądzyńska A. Nadmierne korzystanie z sieci społecznościowych. Alkoholizm i Narkomania 2014; 27(2): 177-194.

10. Kuss DJ, Griffiths MD. Online social networking and addiction - A review of the psychological literature. Int J Environ Res Public Health 2011; 8: 3528-52.

11. Warzecha K. Portale społecznościowe formą rozrywki i komunikacji współczesnej młodzieży - analiza statystyczna. Studia Ekonomiczne. Zeszyty Naukowe Uniwersytetu Ekonomicznego w Katowicach 2017; 318: 84-107.

12. Makaruk K. Korzystanie z portali społecznościowych przez młodzież. Wyniki badania EU NET ADB. Dziecko krzywdzone. Teoria, badania, praktyka 2013; 12(1): 69-79.

13. Boyd D. Participating in the always-on lifestyle. In: Mandiberg M (ed.). The Social Media Reader. New York, NY, USA: New York University Press; 2012.

14. Kuss DJ. Internet gaming addiction: Current perspectives. Psychol Res Behav Manag 2013; 6: 125-37.

15. Cole H, Griffiths MD. Social interactions in massively multiplayer online role-playing gamers. Cyberpsychol Behav 2007; 10: 575-83.

16. Wójcik S. Gry online - korzystanie i nadużywanie wśród młodzieży. Wyniki badania EU NET ADB. Dziecko krzywdzone. Teoria, badania, praktyka 2013; 12(1): 81-98.

17. Maslow AH. A theory of human motivation. Psychol Rev 1943; 50: 370-96.

18. Riva G, Wiederhold BK, Cipresso P. Psychology of social media: From technology to identity. In: Riva G, Wiederhold BK, Cipresso P (eds.). The Psychology of Social Networking: Personal Experience in Online Communities. Warsaw, Poland: De Gruyter Open; 2016, p. 1-11.

19. Caplan SE. Problematic Internet use and psychosocial well-being: development of a theory based cognitive-behavioral measurement instrument. Comput Hum Behav 2002; 18(5): 553-75

20. Davis RA. Cognitive-behavioral model of pathological internet use. Comput Hum Behav 2001; 17(2): 187-95.

21. Frances A, Widiger T. Psychiatric Diagnosis: Lessons from the DSM-IV Past and Cautions for the DSM-5 Future. Annu Rev Clin Psychol 2012; 8: 109-30.

22. Lee EWJ, Ho SS, Lwin MO. Explicating problematic social network sites use: A review of concepts, theoretical frameworks, and future directions for communication theorizing. New Media \& Society 2017; 19(2): 308-26

23. Yellowlees PM, Marks S. Problematic Internet use or Internet addiction? Computers in Human Behavior 2007; 23(3): 1447-53.

24. Billieux J, Schimmenti A, Khazaal Y, Maurage P, Heeren A. Are we overpathologizing everyday life? A tenable blueprint for behavioral addiction research. $J$ Behav Addict 2015; 4: 119-23.

25. Kardefelt-Winther D, Heeren A, Schimmenti A, van Rooij A, Maurage P, Carras M, et al. How can we conceptualize behavioural addiction without pathologizing common behaviours? Addiction 2017; 15: 13763.

26. Kuss DJ, Griffiths MD. Internet gaming addiction: A systematic review of empirical research. Int J Ment Health Addict 2012; 10: 278-96.

27. Kuss DJ, Griffiths MD. Internet Addiction in Psychotherapy. London, UK: Palgrave; 2015. 
28. Griffiths MD, Kuss DJ, Demetrovics Z. Social networking addiction: An overview of preliminary findings. In: Rosenberg K, Feder L (eds.). Behavioral Addictions: Criteria, Evidence and Treatment. New York, NY, USA: Elsevier; 2014, p. 119-41.

29. Buglass SL, Binder JF, Betts LR, Underwood JDM. Motivators of online vulnerability: The impact of social network site use and FOMO. Comput Hum Behav 2017; 66: $248-55$

30. Oberst U, Wegmann E, Stodt B, Brand M, Chamarro A. Negative consequences from heavy social networking in adolescents: The mediating role of fear of missing out. $J$ Adolesc 2017; 55: 51-60.

31. Przybylski AK, Murayama K, DeHaan CR, Gladwell V. Motivational, emotional, and behavioral correlates of fear of missing out. Comput Hum Behav 2013; 29: 1841-8.

32. Bragazzi NL, Del Puente G. A proposal for including nomophobia in the new DSM-V. Psychol Res Behav Manag 2014; 7: 155-60.

33. Turkle S. Alone Together. Why We Expect more from Technology and Less from Each Other. Philadelphia, PA, USA: Basic Books; 2013.

34. Turkle S. Reclaiming Conversation: The Power of Talk in A Digital Age. New York, NY, USA: Penguin; 2015.

35. Kim K, Ryu E, Chon MY, Yeun EJ, Choi SY, Seo JS, et al. Internet addiction in Korean adolescents and its relation to depression and suicidal ideation: a questionnaire survey. Int J Nurs Stud 2006; 43(2): 185-92.

36. Petry NM, Rehbein F, Gentile DA, Lemmens JS, Rumpf HJ, Mößle T, et al. An international consensus for assessing internet gaming disorder using the new DSM-5 approach: Internet gaming disorder. Addiction 2014; 109(9): 1399-406.

37. Subrahmanyam K, Kraut RE, Greenfield PM, Gross EF. The impact of home computer use on children's activities and development. Futur Child 2000; 10(2): 123-44.

38. Bergmark KH, Bergmark A, Findahl O. Extensive Internet involvement - addiction or emerging lifestyle? Int J Environ Res Public Health 2011; 8(12): 4488-501.

39. Bányai F, Zsila Á, Király O, Maraz A, Elekes Z, Griffiths MD, et al. Problematic social media use: Results from a large-scale nationally representative adolescent sample. PLoS ONE 2017; 12: e0169839.

40. Tsitsika AK, Tzavela EC, Janikian M, Ólafsson K, Iordache A, Schoenmakers TM, et al. Online social networking in adolescence: Patterns of use in six European countries and links with psychosocial functioning. J Adolesc Health 2014; 55: 141-7.

41. Sierosławski J. The ESPAD project: history and assumptions. Introduction to series of papers from the ESPAD study 1995-2015. Poland against the background of Europe. Alcohol Drug Addict 2018; 31(1): 1-16.

42. Jarosz-Nowak J. Modele oceny stopnia zgody pomiędzy dwoma ekspertami z wykorzystaniem współczynnika Kappa. Matematyka Stos 2007; 8: 126-54.

43. Welbel M, Mikulska J, Świątkiewicz G. Zgodność rozpoznań określanych za pomocą Złożonego Międzynarodowego Kwestionariusza Diagnostycznego (CIDI) z rozpoznaniami klinicznymi stawianymi przez lekarzy psychiatrów. Postęy Psychiatrii i Neurologii 2013; 22(1): 41-50. 
